\title{
Major Causes of Total Organ Condemnation and their Direct Financial Impact in Cattle Slaughtered at Hawassa Municipality Abattoir, Southern Ethiopia
}

Shimelis Tilahun ${ }^{1}$, Amene Fekadu $^{2 *}$ and Berhanu Mekibib ${ }^{2}$

${ }^{1}$ Chiko Wereda Animal and Fishery Department, Hawassa University, P O Box 05, Awassa, Ethiopia

${ }^{2}$ School of Veterinary Medicine, Hawassa University, P.O.Box 05, Awassa, Ethiopia

*Corresponding author: Amene Fekadu, School of Veterinary Medicine, Hawassa University, P. O. Box 05, Awassa, Ethiopia, Tel: +251-911300314; E-mail: amenef@gmail.com

Rec date: August 29, 2017; Acc date: September 19, 2017; Pub date: September 21, 2017

Copyright: ( 2017 Tilahun S, et al. This is an open-access article distributed under the terms of the Creative Commons Attribution License, which permits unrestricted use, distribution, and reproduction in any medium, provided the original author and source are credited.

\begin{abstract}
The study was conducted to identify major causes of total organs condemnation in cattle slaughtered at Hawassa city municipal abattoir and to estimate the associated direct financial losses. To this effect, a cross sectional active abattoir survey was conducted on 609 cattle from October 2015 to April 2016. During ante mortem examination, various types of abnormalities were detected in $39(6.4 \%)$ cattle which includes rough hair coat $8(1.3 \%)$, teeth grinding $7(1.2 \%)$, dyspnea $5(0.8 \%)$, diarrhea $5(0.8 \%)$, lameness $4(0.7 \%)$, nasal discharge $2(0.3 \%)$, blindness $2(0.3 \%)$, early LSD signs $2(0.3 \%)$, dry muzzle $2(0.3 \%)$, paraphimosis $1(0.2 \%)$ and gangrenous testis $1(0.2 \%)$. On postmortem examination inspected, $96.1 \%(585)$ of the examined lungs $(n=609)$ were condemned due to different disease conditions such as pneumonia $(43.2 \%)$, hydatid cyst $(24.8 \%)$, emphysema $(18.9 \%)$, atelectasis $(14.9 \%)$, and congestion (1\%). Similarly, $63.1 \%$ of livers inspected were condemned due to fasciolosis $(24.3 \%)$, calcification $(15.3 \%)$, fibrosis $(10.3 \%)$, fatty change $(4.4 \%)$ and abscessation $(1.8 \%)$. Heart and kidneys also had various abnormalities. The study further revealed that a total of 2,535,022.42 ETB (116, 611.03 USD) was lost due to the organs condemned during the active abattoir survey. To reduce organ condemnation rate and hence the associated financial loss and public health consequences, educating the public/the concerned bodies to avoid eating of raw meat, to improve canine health care and cattle management systems, to institute stray dog population management, to properly dispose condemned organs, and to implement regular deworming with effective anti-helminths are important. Moreover, proper and detail meat inspection at the abattoir and proper disposal or incineration of condemned organs are also recommended.
\end{abstract}

Keywords: Cattle; Cause of organ condemnation; Financial loss

\section{Introduction}

Abattoirs played an important role in surveillance of various disease of human and animal health importance. Surveillance at the abattoir allows all animals passing in to human food chain to be examined for unusual signs, lesions or specific disease [1]. Records of ante and postmortem inspections are useful epidemiological data for the evaluation of diseases at farm level, to estimate financial loss incurred through condemnation of affected organs and carcasses [2] and to verify the efficacy of prophylactic and therapeutic interventions [3,4]. The activity also provides vital data and valuable information on the incidence and prevalence of animal diseases and conditions within any country [5].

The gross pathological changes that cause organs and carcasses condemnation during post mortem inspection are often caused by parasites, bacteria and other etiological agents. The final judgment as to action to be taken with an organ, carcass or part of carcass is based on the total evidence produced by the visual observation, palpation and incision [6].

Determination of the cause and magnitude of organ and carcass condemnation in animals at abattoir and proper evaluation of associated economic losses are needed where economic realities often determined the type and scope of prevalence measures to be used [7].

Even though several studies have been conducted in different parts of the country [5,8-10], most of them focused on specific disease conditions like fasciolosis, hydatidosis and Cysticercus bovis. Moreover, there is no work done in Hawassa Municipality Abattoir and the issue requires further study to investigate the full list of causes of organ condemnation and to estimate the associated direct financial impacts and hence suggest some feasible control measures.

Therefore, this work was conducted to know the major causes of total organ condemnation and to estimate the direct financial loss because of total organs condemned.

\section{Materials and Methods}

\section{Description of study area}

The study was conducted in Hawassa, the capital city of southern nations, nationalities, and people's region. Hawassa is located at 275 $\mathrm{km}$ south of Addis Ababa. Geographically it lies between $4^{\circ} 27^{\prime}$ and $8^{\circ} 30^{\prime}$ latitude north and $34^{\circ} 21^{\prime}$ and $39^{\circ} 1^{\prime}$ east longitude [11]. 
Citation: Tilahun S, Fekadu A, Mekibib B (2017) Major Causes of Total Organ Condemnation and their Direct Financial Impact in Cattle Slaughtered at Hawassa Municipality Abattoir, Southern Ethiopia. J Vet Sci Technol 8: 473. doi:10.4172/2157-7579.1000473

Page 2 of 5

\section{Study population and study animals}

The study population was the total number of cattle presented to the abattoir for slaughter from different areas such as Tula, Arsi Negele, Shashemene, Harar, Hawassa, Negele Borana, Asassa, TikurWuha, Cofele, Dodola, Bore, Yabelo, Kibre Mengist and Nazareth. The study animals were randomly selected from the study population based on paints (numbers) on their body for identification.

\section{Sampling procedure and study design}

The study was conducted on randomly selected cattle slaughtered at the abattoir. For this study systematic random sampling method was employed to include the representative cattle from those slaughtered from October 2015 to April 2016. Therefore, cross-sectional study design was employed to generate prospective data and retrospective data was also collected to calculate/estimate the financial loss.

\section{Abattoir survey}

During ante mortem inspection each of the study animals were given identification with paint on their body and all the necessary independent variables such as age, sex and body condition score were recorded. Body condition score of these animals was recorded by applying the procedure shown by Nicholson and Butterworth [12]. Their age was estimated by examining the tooth eruption using the approach forwarded by De Nahunta and Habel.

Ante mortem inspection was conducted on individual animals entering in to the lairage and after they entered into the lairage in mass. The general behavior of the animal, nutritional status, gait, posture, cleanliness, clinical signs suggestive of disease and abnormality of any type were registered [13] and judgment was made based on FAO recommendation [14]. Cattle with observable abnormality were not allowed for slaughter because they are unfit for human consumption.

During post mortem inspection, liver, lung, heart and kidney were thoroughly inspected by visualization, palpation and making systemic incisions to check for the presence of cyst, parasite and/or other abnormalities. Pathological lesions were differentiated and judged according to guidelines on meat inspection for developing countries [15] and classified in to the following categories of judgments: approved as fit for human consumption, conditionally approved as fit for human consumption, totally condemned as unfit for human consumption and partially condemned as fit for human consumption $[15,16]$.

\section{Assessment of direct financial loss}

The financial loss due to organ condemnation was analyzed based on the average annual slaughter capacity of the abattoir, average market price of each organ in Hawassa city and rejection rate of each organ. Average market price was determined based on the interview made with 50 personnel of the abattoir and different butchers. The financial loss due to condemnation of organs was estimated by the formula set by Ogunrinade as follows [17]:

$$
\mathrm{EL}=\Sigma \mathrm{srx}^{\star} \mathrm{Coy}^{*} \mathrm{Roz}
$$

Where

$\mathrm{EL}=$ Annual economic loss estimated due to organ condemnation

$\Sigma$ srx=Annual cattle slaughter of the abattoir.
Coy=Average cost of each cattle liver/lung/heart/kidney

Roz=Condemnation rate of each cattle liver/lung/heart/kidney.

\section{Data management and statistical analysis}

Data generated from longitudinal ante mortem and post mortem inspections were recorded in spreadsheet of Micro Soft EXCEL, coded, and analyzed using Stata software (STATA, 2013; window version 13.1). Descriptive statistics was used to determine the level of organ condemnation, defined as the proportion of condemned organs to the total number of organs examined. Association between the considered risk factors and the proportion of organ(s) condemnation was analyzed using chi-square test. In all the analysis, the study considered $95 \%$ level of significance and $5 \%$ desired level of precision.

\section{Results}

\section{Ante mortem examinations}

During the study period, different abnormalities were detected on $39(6.4 \%)$ of the cattle examined ante mortem. Rough hair coat, teeth grinding, dyspnea, diarrhea, lameness, nasal discharge, blindness, early LSD signs, dry muzzle, paraphimosis and gangrenous testis were the abnormalities detected (Table 1).

\begin{tabular}{|c|c|c|c|}
\hline $\begin{array}{l}\text { Abnormality } \\
\text { found }\end{array}$ & $\begin{array}{l}\text { No of abnormalities } \\
\text { found }\end{array}$ & $\begin{array}{l}\% \\
\text { abnormality }\end{array}$ & Judgments \\
\hline Rough hair coat & 8 & 1.3 & \multirow{11}{*}{$\begin{array}{l}\text { Passed for } \\
\text { slaughter but } \\
\text { with special } \\
\text { attention during } \\
\text { post mortem } \\
\text { examinations }\end{array}$} \\
\hline Teeth grinding & 7 & 1.2 & \\
\hline Dyspnea & 5 & 0.8 & \\
\hline Diarrhea & 5 & 0.8 & \\
\hline Lameness & 4 & 0.7 & \\
\hline Nasal discharge & 2 & 0.3 & \\
\hline Blind & 2 & 0.3 & \\
\hline Early LSD sign & 2 & 0.3 & \\
\hline Dry muzzle & 2 & 0.3 & \\
\hline Paraphimosis & 1 & 0.2 & \\
\hline $\begin{array}{l}\text { Gangrenous } \\
\text { testis }\end{array}$ & 1 & 0.2 & \\
\hline
\end{tabular}

Table 1: Summary on the findings of ante mortem inspection $(n=609)$.

\section{Post mortem examinations}

Among 609 lungs inspected, 96.1\% (585) of them were condemned due to different disease conditions such as pneumonia (43.2\%), hydatid cyst $(24.8 \%)$, emphysema $(18.9 \%)$, atelectasis $(14.9 \%)$, and congestion (1\%). Similarly, $384(63.1 \%)$ of livers inspected were condemned due to fasciolosis $(24.3 \%)$, calcification (15.3\%), fibrosis $(10.3 \%)$, fatty change $(4.4 \%)$ and abscessation (1.8\%). Heart and kidneys also had various abnormalities (Tables 2 and 3 ).

\begin{tabular}{|l|l|l|l|}
\hline Organ & Abnormality & Rejection rate (\%) & $\begin{array}{l}\text { Annual loss of money } \\
\text { (ETB/USD) }\end{array}$ \\
\hline
\end{tabular}


Citation: Tilahun S, Fekadu A, Mekibib B (2017) Major Causes of Total Organ Condemnation and their Direct Financial Impact in Cattle Slaughtered at Hawassa Municipality Abattoir, Southern Ethiopia. J Vet Sci Technol 8: 473. doi:10.4172/2157-7579.1000473

Page 3 of 5

\begin{tabular}{|c|c|c|c|}
\hline \multirow{5}{*}{ Lung } & Pneumonia & 43.2 & $5,40,328.30$ \\
\hline & Hydatid cyst & 24.8 & $3,10,188.50$ \\
\hline & Emphysema & 18.9 & $2,36,393.60$ \\
\hline & Atelectasis & 14.9 & $1,86,363.20$ \\
\hline & Congestion & 1 & $12,507.60$ \\
\hline \multirow{5}{*}{ Liver } & Fasciolosis & 24.3 & $3,90,773.20$ \\
\hline & Calcification & 15.3 & $2,46,042.30$ \\
\hline & Fibrosis & 10.3 & $1,65,636.40$ \\
\hline & Fatty change & 4.4 & $70,757.28$ \\
\hline & Abscessation & 1.8 & $28,946.16$ \\
\hline \multirow{5}{*}{ Heart } & $\begin{array}{l}\text { Hydro } \\
\text { pericardium }\end{array}$ & 1.3 & $8,129.94$ \\
\hline & $\begin{array}{l}\text { Pericardial } \\
\text { adhesion }\end{array}$ & 0.3 & $1,876.14$ \\
\hline & Hydatid cyst & 0.16 & $1,00,060.80$ \\
\hline & C. bovis & 0.16 & $1,00,060.80$ \\
\hline & Calcification & 0.16 & $1,00,060.80$ \\
\hline \multirow{2}{*}{ Kidney } & Kidney stone & 0.3 & $1,876.14$ \\
\hline & Paleness & 0.1 & 625.38 \\
\hline
\end{tabular}

Table 2: Respective organ condemnation rates and the corresponding annual financial loss (average number of cattle Slaughtered per year $=17,868)$.

\begin{tabular}{|c|c|c|c|c|c|c|}
\hline Variable & $\begin{array}{l}\text { Categorie } \\
\mathrm{s}\end{array}$ & $\begin{array}{l}\text { No } \\
\text { inspecte } \\
\text { d }\end{array}$ & Lung & Liver & Heart & $\begin{array}{l}\text { Kidne } \\
y\end{array}$ \\
\hline \multirow{3}{*}{$\begin{array}{l}\text { Age } \\
\text { (year) }\end{array}$} & $<4$ & 30 & $29(96.7 \%)$ & $17(56.7 \%)$ & $0(0 \%)$ & $0(0 \%)$ \\
\hline & $\geq 4$ to $6 \leq$ & 386 & $\begin{array}{l}367(95.1 \% \\
)\end{array}$ & $\begin{array}{l}232(60.1 \% \\
)\end{array}$ & $2(0.5 \%)$ & $4(1 \%)$ \\
\hline & $>6$ & 193 & )$^{189(97.9 \%}$ & $\begin{array}{l}135(69.9 \% \\
)^{2}\end{array}$ & $4(4.1 \%)$ & $\begin{array}{l}4(2.1 \\
\%)\end{array}$ \\
\hline \multirow{2}{*}{ BCS } & Medium & 481 & $461(95.8 \%$ & $312(64.9 \%$ & $7(1.4 \%)$ & $\begin{array}{l}8(1.7 \\
\%)\end{array}$ \\
\hline & Good & 128 & $124(96.9 \%$ & $72(56.3 \%)$ & $3(2.3 \%)$ & $0(0 \%)$ \\
\hline \multirow{2}{*}{ Sex } & Female & 18 & $16(88.9 \%)$ & $11(61.1 \%)$ & $0(0 \%)$ & $0(0 \%)$ \\
\hline & Male & 591 & $\begin{array}{l}569(96.3 \% \\
)\end{array}$ & $\begin{array}{l}373(63.1 \% \\
)^{3}\end{array}$ & $\begin{array}{l}10(1.7 \\
\%)\end{array}$ & $\begin{array}{l}8(1.4 \\
\%)\end{array}$ \\
\hline \multirow{2}{*}{ Breed } & Local & 542 & $\begin{array}{l}523(96.5 \% \\
)\end{array}$ & $\begin{array}{l}348(64.2 \% \\
)^{2}\end{array}$ & $\begin{array}{l}10(1.8 \\
\%)\end{array}$ & $\begin{array}{l}8(1.5 \\
\%)\end{array}$ \\
\hline & Cross & 67 & $62(92.5 \%)$ & $36(53.7 \%)$ & $0(0 \%)$ & $0(0 \%)$ \\
\hline
\end{tabular}

Table 3: Rejection rate of specific organs stratified with the putative risk factors $(\mathrm{n}=609)$.

\section{Direct financial loss assessment}

Based on 5 years retrospective abattoir data, the average annual slaughter of Hawassa municipal abattoir was estimated to be 17,868 cattle. The estimated annual financial loss associated with condemnation of liver, lung, kidneys and heart collectively was found to be 2,535,022.42 ETB (estimated to be 116, 611.03 USD) (Table 4). Condemnation of lung represented the highest financial losses (47\%) of all the losses followed by liver (40\%), heart (12.2\%) and kidney $(0.3 \%)$.

\begin{tabular}{|l|l|l|l|}
\hline Type of organ & $\begin{array}{l}\text { Rejection rate } \\
\text { (\%) }\end{array}$ & $\begin{array}{l}\text { Average price of } \\
\text { an organ }\end{array}$ & $\begin{array}{l}\text { Annual loss of } \\
\text { money (ETB) }\end{array}$ \\
\hline Lung & 96.1 & 70 & $12,01,980$ \\
\hline Liver & 63.1 & 90 & $10,14,724$ \\
\hline Heart & 1.6 & 35 & $3,10,188.48$ \\
\hline Kidney & 1.3 & 35 & $8,129.94$ \\
\hline Total & & & $25,35,022.42$ \\
\hline
\end{tabular}

Table 4: Annual financial loss due to condemnation of organs (average annual slaughtered cattle $=17868$ ).

\section{Discussion}

This study showed that pneumonia, hydatid cyst, emphysema, atelectasis, congestion, fasciolosis, calcification, fibrosis, fatty change, abscessation, hydropericardium, pericardial adhesion, kidney stone and kidney paleness were the major causes of organs condemnation in cattle slaughtered at Hawassa municipal abattoir. From the total of 609 cattle slaughtered, lung (96.1\%), liver (63.1\%), heart (1.6\%) and kidney (1.3\%) were condemned due to different lesions. Lung was rejected due to pneumonia, hydatid cyst, emphysema, atelectasis and congestion with the rates of $43.2 \%, 24.8 \%, 18.9 \%, 14.9 \%$ and $1 \%$ respectively. The total lung condemnation (96.1\%) rate was much higher than $(46.22 \%)$ the report by Amene et al. [8] from Jimma municipal abattoir. The prevalence of hydatid cyst on the Lung $(24.8 \%)$ was lower than the reports made by Abebe and Yilma [18] and Amene et al. [8], who reported prevalence of $27.98 \%$ and $35.85 \%$ from different part of the country and Jimma Municipal Abattoir, respectively. However, the current finding is higher than the report of Efrem et al. [19] from Nekemte Municipal Abattoir (12.17\%). The lung is the most frequently affected organ by hydatidosis due to its size, blood supply and availability of oxygen supply (Urquhart et al.) [20]. Emphysema was also the cause for lung condemnation with rejection rate of $18.9 \%$, which is higher than the rate $(1.61 \%)$ reported by Alembrhan and Haylegebriel [21], 1.62\% reported by Nebyou et al. [10] and $1.2 \%$ reported by Fasil [22] from Adigrat Municipal, Nekemte Municipal and Gondar Elfora Abattoirs, respectively.

Generally speaking, of all the organ systems, the respiratory tract particularly the lung is unique in its vulnerability to various injurious agents. The involuntary nature of ventilation actively pulls large volumes of air into the lungs along with a variety of potentially injurious materials/organisms. In addition, the lung is acting as a septic organ where all potentially harmful substances/organisms are disposed the moment the entire cardiac output is passing through the extensive and delicate vascular bed of the gas exchange region of the lungs [23].

Livers were rejected due to fasciolosis (24.3\%), calcification (15.3\%), fibrosis $(10.3 \%)$, fatty change $(4.4 \%)$ and abscessation (1.8\%) which 
account to the total rejection rate of $63.1 \%$. Since the liver is damaged by several infectious and non-infectious causes, majority of the liver examined will not be destined for human consumption either because of aesthetic reasons or fear of zoonotic diseases. Injurious agents enter into the liver through hematogenous port of entry, retrograde through biliary and pancreatic ducts and via direct extension through liver capsule $[24,25]$. The liver rejection rate recorded in this study is higher than the reports made by Alembrhan and Haylegebriel and Yifat et al. [5,21] who reported $17.58 \%$ and $31.1 \%$ from Adigrat municipal abattoir and Gondar Elfora Abattoir, respectively. In line with the current finding, different researchers also indicated that fasciolosis was the leading cause of liver condemnation (Yifat et al.; Alembrhan and Haylegebriel; Fufa and Debele [5,9,21]. Comparable fasciola prevalence (24.24\%) was reported by Fufa and Debele [9] from Wolaita Sodo Municipal Abattoir. However, Atawalna et al. [26] reported a lower prevalence (2.39\%) from the Bolgatanga Municipal Abattoir of Ghana. The report from Hashim Nur's Export Abattoir (located in DebreZeit town) by Abdulhakim and Addis [27] showed the prevalence of $39.8 \%$ which is higher than the present finding of $24.3 \%$. Such variation among the different reports could be derived from the difference in ecology, management and husbandry system and veterinary health service in the origin of the animals included in the studies.

Calcification caused liver condemnation of $15.3 \%$ showing higher prevalence than the reports by Fufa and Debele [9] and Nebyou et al. [10], which were $2.73 \%$ and $4.16 \%$ in Wolaita Sodo and Nekemte Municipal Abattoirs, respectively. Fibrosis, another pathological condition causing rejections of livers, observed in the present study (with rejection rate of $10.3 \%$ ) was higher than $(0.56 \%)$ the report by Efrem et al. [19] from Nekemte Municipal Abattoir. Abscessation having a prevalence of $1.8 \%$ was slightly higher than the prevalence (1.17\%) reported by Atawalna et al. [26] from the Bolgatanga Municipal Abattoir of Ghana. These variations in prevalence could be due to management systems, ecological locations and less public understanding about the conditions.

Heart was also condemned due to different pathological conditions such as hydropericardium, pericardial adhesion, hydatid cyst, Cysticercus bovis and calcification. Among these hydropericardium and pericardial adhesion were the major causes of heart condemnations with respective prevalence of $1.3 \%$ and $0.3 \%$. Kidney stone and kidney paleness caused the condemnations of kidneys having respective rejection rates of $0.3 \%$ and $0.1 \%$.

The effort made to see the association of organ rejection rate with the different animal risk factors revealed that the rejection rate increased with the age of the cattle slaughtered this could be due to reduction in immunity when animals become old and the decreasing wound healing and repair capacity. However, there was no statistically significant difference in the rejection rate of lung, liver and kidneys among the 3 age categories. There was also an association between body conditions scores and rejection rates of lung and heart with increased body conditions but no association among liver and kidneys rejection rates and body condition scores. Lung, liver, heart and kidneys rejection rates were higher in males than female bovines and in local breeds than in cross breeds. However, we can't deduce the possible factors for such non proportional sampling. Therefore, further research having equal or comparable number of animals in each category is required to know their association whether significant or not.

In the present study a total annual financial loss of 2,535,022.42 ETB $(116,611.03$ USD) was recorded because of organ rejection at post mortem inspections due to different disease conditions (lesions) in different visceral organs. This is very much higher than the economic losses reported from Gondar Elfora Abattoir (150,048.98 ETB), and Jimma (172,664.09 ETB) Municipal Abattoir by Fasil [22] and Amene et al. [8], respectively. The observed variation on the financial losses due to condemnations of organs at different abattoirs could be due to differences in animal management systems, disease prevalence, slaughtering capacity of the abattoir, rejection rates of organs, condemnation system of affected organs, and lack of public awareness about the diseases and prices of organs in the respective markets.

\section{Conclusion and Recommendations}

These findings of the present study showed that different disease conditions such as pneumonia, hydatid cyst, emphysema, atelectasis, congestion, fasciolosis, calcification, fibrosis, fatty change, absceessation, hydro pericardium, pericardial adhesion and kidney stone and kidney paleness were causes of organ condemnations in Hawassa Municipal Abattoir that lead to a large amount of financial losses $(2,535,022.42$ ETB) $(116,611.03$ USD) per year. To reduce the associated financial loss and possible public health consequences, these problems need to be reduced and eradicated, if possible. Reduction and eradication of these diseases require cooperation between the public health and official veterinary authorities. Public health education to avoid eating of raw meat, canine health care, stray dog population management, proper disposal of condemned organs, cattle management system, regular deworming of cattle with effective antihelminthes and grazing management of animals during dry season to avoid access of the animals to the parasites eggs are important. In addition to awareness creation, proper and detail meat inspection at the abattoir are also recommended and training should be offered to abattoir workers on the overall consideration in the due course of slaughtering, inspection, dispatch of inspected carcass and incineration of condemned organs. Special emergency slaughter house is important and required as much as possible. Abattoirs have to be supplied with ample water supply, electric supply and waste disposal systems have to be given special attention by the abattoir personnel.

\section{References}

1. Alton GD, Lpeah D, Bateman KJ, Mc Nab WB, Berk O (2010) Factors associated with whole carcass condemnation rates in provincially inspected abattoir in Ontario 2001-2007: Implication for food animal syndromic surveillance. BMC Vet Res 6: 42 .

2. Cadmus SIB, Adesokan HK (2009) Causes and implication of bovine organs/offal condemnations in Abattoirs in Western Nigeria. Trop Anim Health Prod 41: 1455-1463.

3. Antia RE (1982) Survey of abattoir data in Southern Nigeria. Trop Anim Health Prod 14: 2.

4. Raji MA, Salami V, Ameh JA (2010) Pathological conditions and lesions observed in slaughtered cattle in Zaria Abattoir. J Clin Pathol Forensic Med 1: 9-12.

5. Yifat D, Gedefaw D, Desie S (2011) Major causes of organ condemnation and financial significance of cattle slaughtered at Gondar Elfora Abattoir, Northern Ethiopia. Glob Vet 7: 487-490.

6. Teka G (1997) Meat Hygiene, principles and methods of food Borne diseases control with special reference to Ethiopia Addis Ababa University, Faculty of Veterinary Medicine Department Community Health, Ethiopia, pp: 99-113.

7. Jibat $\mathrm{T}$ (2006) Cause of organ and carcasses condemnation at Asella Municipal Abattoir. DVM Thesis, Addis Ababa University, Faculty of Veterinary Medicine, Debre Zeit, Ethiopia, pp: 1-12. 
Citation: Tilahun S, Fekadu A, Mekibib B (2017) Major Causes of Total Organ Condemnation and their Direct Financial Impact in Cattle Slaughtered at Hawassa Municipality Abattoir, Southern Ethiopia. J Vet Sci Technol 8: 473. doi:10.4172/2157-7579.1000473

Page 5 of 5

8. Amene F, Eskindir L, Dawit T (2012) The cause, rate and economic implication of organ condemnation of cattle slaughtered at Jimma Municipal Abattoir, Southwestern Ethiopia. Glob Vet 9: 396-400.

9. Fufa A, Debele H (2013) Major causes of organ condemnation for cattle and its financial impact at Wolaita Soddo Municipality Abattoir, Southern Ethiopia. Glob Vet 11: 730-734.

10. Nebyou M, Debela A, Solomon K, Tesema T, Fanta D, et al. (2014) Major Causes of organs and carcass condemnation in cattle slaughtered at Nekemte Municipality Abattoir, East Wollega, Ethiopia. Glob Vet 13: 278-284.

11. Asmare A, Biniyam A, Mersha C (2012) Major causes of lung and liver condemnation and financial impact in cattle slaughter at Bahir Dar Municipial Abattoir. African J Basic Appl Sci 4: 165-171.

12. Nicholson MJ, Butterworth $\mathrm{MH}$ (1986) A guide to condition scoring of zebu cattle. ILCA, Addis Ababa, Ethiopia, pp: 212-235.

13. Gracey JF, Collins DS, Huey RJ (1999) Meat Hygiene, 3rd edn. WB Saunders Company Ltd., pp: 669-678.

14. Food and Agriculture Organization (1994) Manual of meat inspection for developing countries. FAO. Anim Prod Health, pp: 119-359.

15. Herenda D, Chambers PG, Ettriqui A, Seneviratna P, Da Silva TJP (1994) Manual on meat inspection for developing countries. FAO, Rome.

16. Getachew EW (2008) Major diseases of export oriented livestock in export Abattoirs in/around Ada Liben Wereda, DedbreZeit, Faculty of Veterinary Medicine and Haramaya University, Ethiopia, DVM Thesis.

17. Orgurinade A, Orgurinade BI (1980) Economic importance of bovine fasciolosis in Nigeria. Trop Anim Heal Prod 12: 155-160.

18. Abebe F, Yilma J (2012) Estimated annual economic loss from organ condemnation, decreased carcass weight and milk yield due to bovine hydatidosis (Echinococcus granulosus, Batsch, 1786) in Ethiopia. Ethiop Vet J 16: 1-14.
19. Efrem L, Biresaw S, Berhanu S, Eyob H (2015) Causes of organ condemnation, its public health and financial significance in Nekemte Municipal Abattoir, Wollega, Western Ethiopia. J Vet Med Anim Health 7: 205-214.

20. Urquhart GM, Armor J, Duncan JL, Duna AM, Jennings FW (1996) Veterinary Parasitology. 2nd edn. Scotland: Black Well Science, pp: 122-129.

21. Alembrhan A, Haylegebriel $T$ (2013) Major causes of organ condemnation and economic loss in cattle slaughtered at Adigrat Municipal Abattoir, northern Ethiopia. Vet World 6: 734-738.

22. Fasil B (2009) Major causes of organ condemnation in cattle slaughtered at Gondar Elfora Abattoir. Faculty of Veterinary Medicine, Jimma University, Jimma, Ethiopia, DVM Thesis.

23. Caswell JL, Williams KJ (2007) Respiratory system. In: Maxie MG (eds.) Jubb, Kennedy, and Palmer's Pathology of Domestic Animals. Vol. 2. Edinburgh: Elsevier; pp. 523-654.

24. Stalker MJ, Hayes MA (2007) Liver and biliary system. In: Maxie MG (eds.) Jubb, Kennedy, and Palmer's Pathology of Domestic Animals. Vol. 2. Edinburgh: Elsevier, pp: 298-387.

25. Mc Gavin MD, Zachary JF (2006) Pathologic Basis of Veterinary Disease. 4th edn. Mosby, Elsevier, pp: 393-418.

26. Atawalna J, Gbordzi M, Emikpe BO, Anyorigeyah T (2016) Whole carcass and organ condemnation and their associated financial losses in ruminants slaughtered at the Bolgatanga Municipal Abattoir of Ghana. Int J Vet Sci 5: 5-9.

27. Abdulhakim Y, Addis M (2012) An abattoir study on the prevalence of fasciolosis in Cattle, Sheep and Goats in DebreZeit Town, Ethiopia. Glob Vet 8: 308-314. 